\title{
SENTIMENT ANALYSIS OF MICROTAKAFUL INDUSTRY: COMPARISON OF INDONESIA AND MALAYSIA
}

\author{
Aam Slamet Rusydiana \\ Researcher and Consultant at Sharia Economic Applied Research and Training (SMART) \\ Consulting Indonesia \\ Email: aamsmart@gmail.com \\ Irman Firmansyah \\ Lecturer at Accounting Department, Siliwangi University, and researcher at SMART Consulting \\ Lina Marlina \\ Lecturer at Islamic Economics Department, Siliwangi University
}

\begin{abstract}
It is important to do research on public sentiment towards microtakaful presence in a country in order to know public response to its existence. This study aimed to determine public sentiment towards microtakaful in Indonesia and in Malaysia. Data were collected from 40 articles, journals and other writings. Data were analysed using the software Semantria as an analytical tool in the form of text. The results showed that the assessment of existence of microtakaful in Indonesia amounted to $52 \%$ of the community showed positive sentiment, $28 \%$ indicate negative sentiment and $20 \%$ indicates a neutral sentiment. While in Malaysia that $62 \%$ showed positive sentiment, $23 \%$ negative sentiment and $15 \%$ neutral sentiment.
\end{abstract}

Keywords: Microtakaful, Sentiment, Islamic insurance

\section{A. INTRODUCTION}

Indonesia is one of country that is applying double financial system, namely the conventional financial system and Islamic (sharia) financial system. Islamic finance in Indonesian emerged around 1992, spearheaded by Bank Muamalat Indonesia. Once it starts growing Islamic Banks, Islamic Business Unit, Saria Rural Bank, Sharia Cooperation, Takaful, Islamic pawnshop, Wakaf, Zakat and Islamic Financial Institutions. Taken together, the Islamic financial system and conventional financial system synergistically support the mobilization of public funds more widely to improve funding for sectors of the national economy.

The Indonesia society that Muslim-majority which makes the growth of Islamic financial industry increasingly showing significant growth rate. Even when compared with the growth of conventional financial industry, Islamic finance industry's growing very rapidly from year to year. In 2009 until 2013 comparative growth in assets of Islamic financial industry is higher than the growth of assets 
in the conventional financial industry. This growth is not only happening in the GCC countries, but also some other countries. The growth of the Islamic financial industry assets in Indonesia reached 43\% (Hussein, et al, 2015).

The function and role of Islamic financial economy and the financial system is more than expected, especially the experience of the financial crisis has been reviving the essence of the activity of financial institutions (Nurfalah etal, 2018). Economic and Islamic finance, has been based in concept to real transactions which does not ignore the practice of speculation and financial fundamentals and the real, so as not to cause any bubble in the economy and financial system. Economic and Islamic finance system are present based on the achievement of justice and the distribution of economic prosperity and ethical values that are universal, that is acceptable to all parties. In practical terms, in the end the economic and Islamic finance provides a clear line of connection that product and financial transactions that occur in the market should be highly relevant and directly related to the real sector (FSA: 2013).

According Ascarya et. al (2006) there are at least five factors that favor the development of Islamic financial system and the economy in Indonesia. First, the fatwa that bank interest is usury and haram. Second, the trend of the Muslim community awareness is increasing, especially in the upper middle-class society. Third, the Islamic economic system managed to show its superiority, proven in times of economic crisis. When conventional banks collapsed and needed an injection of government funds to hundreds of trillions, Bank Muamalat Indonesia, as the first Islamic bank in Indonesia, is able to pass through the crisis safely and without a penny of government funding. Fourth, the Islamic Banking Act that is now continually drafted, will be the legal basis for Islamic banking in Indonesia. Fifth, demands the integration of Islamic Financial Institutions are mutually reinforcing. As examples of Islamic banks can use Islamic insurance to cover the risk of financing to its customers. In contrast, Islamic insurance can save their money in Islamic banks, Islamic capital markets, as well as Islamic mutual funds (Ascarya et. al, 2006).

in Indonesia, the bank has a market share of $80 \%$ of all existing financial institutions. Given the magnitude of the role of banks in Indonesia, decision makers need to pass an adequate performance evaluation (Abidin, 2007). The growth of Islamic banking shows a figure likely to increase from year to year although in 2015 slowed down the increase. However, the growth of Islamic banking still relatively high compared to banks in general and the global Islamic financial amidst Indonesia's economy is slowing, it proves that Islamic banking in Indonesia with its characteristics and support relevant stakeholders, has been able to maintain its existence. 


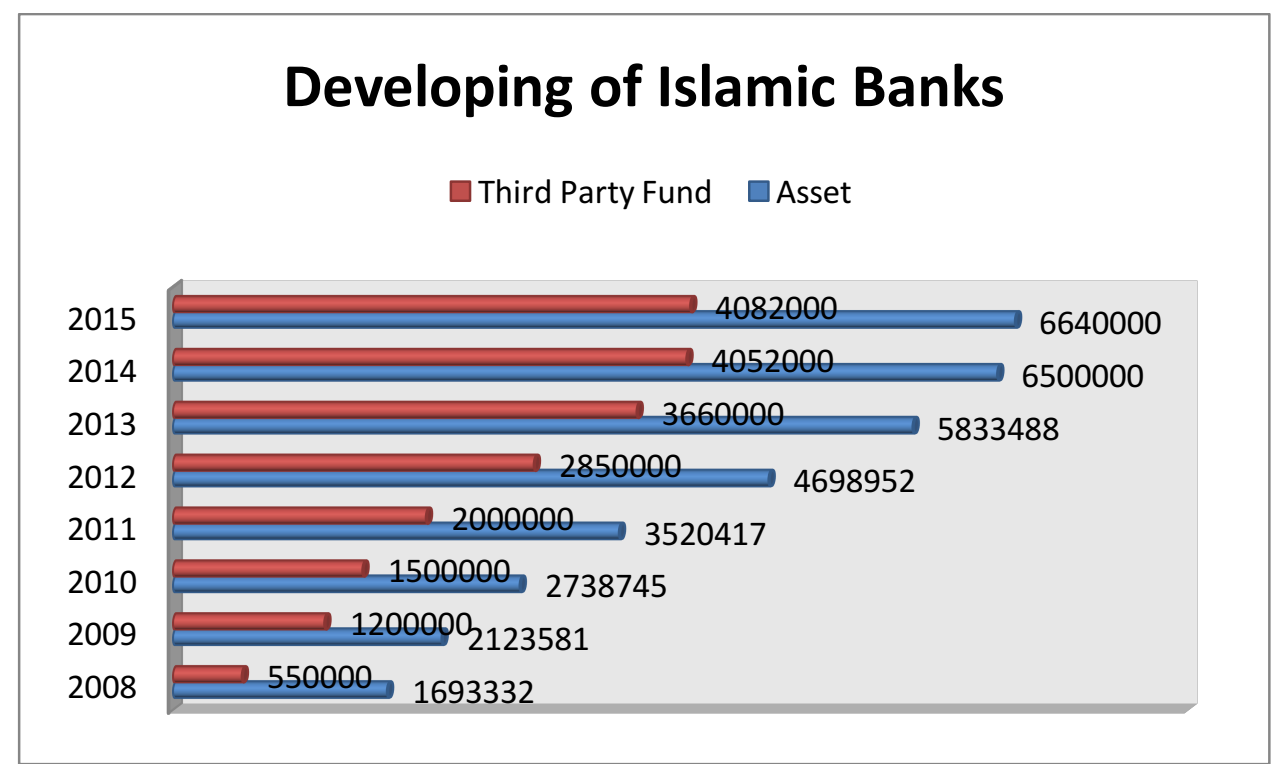

Figure 1: Developing of Islamic Bank in Indonesia

Source: Bank Indonesia

From the figure above it can be seen, despite the slowdown in late 2015, the rate of growth of assets and deposits in Islamic banking is still higher than the growth of national banking assets. In addition, asset growth is still followed by the implementation of the optimal intermediation function. In addition, the development of Islamic financial institutions cannot simply rely on the development of Islamic banking as a separate institution. In the history of development in the world, Islamic banking development is inseparable from the development of Islamic financial system as a whole, all aspects and infrastructure in the Islamic financial system is basically intertwined.

Islamic finance industry consists of the bank financial industry and non-bank financial industry. The growth of non-bank financial industry is not as good as the growth of the bank financial industry. Based Islamic Financial Stability Report/IFSB (2014) stated that the composition of the assets of non-bank financial industry as an example insurance, Islamic finance institutions and others, no more than half the growth of the bank financial industry. But if we look at the development of Islamic insurance in Indonesia show that Islamic insurance in Indonesia is growing very fast.

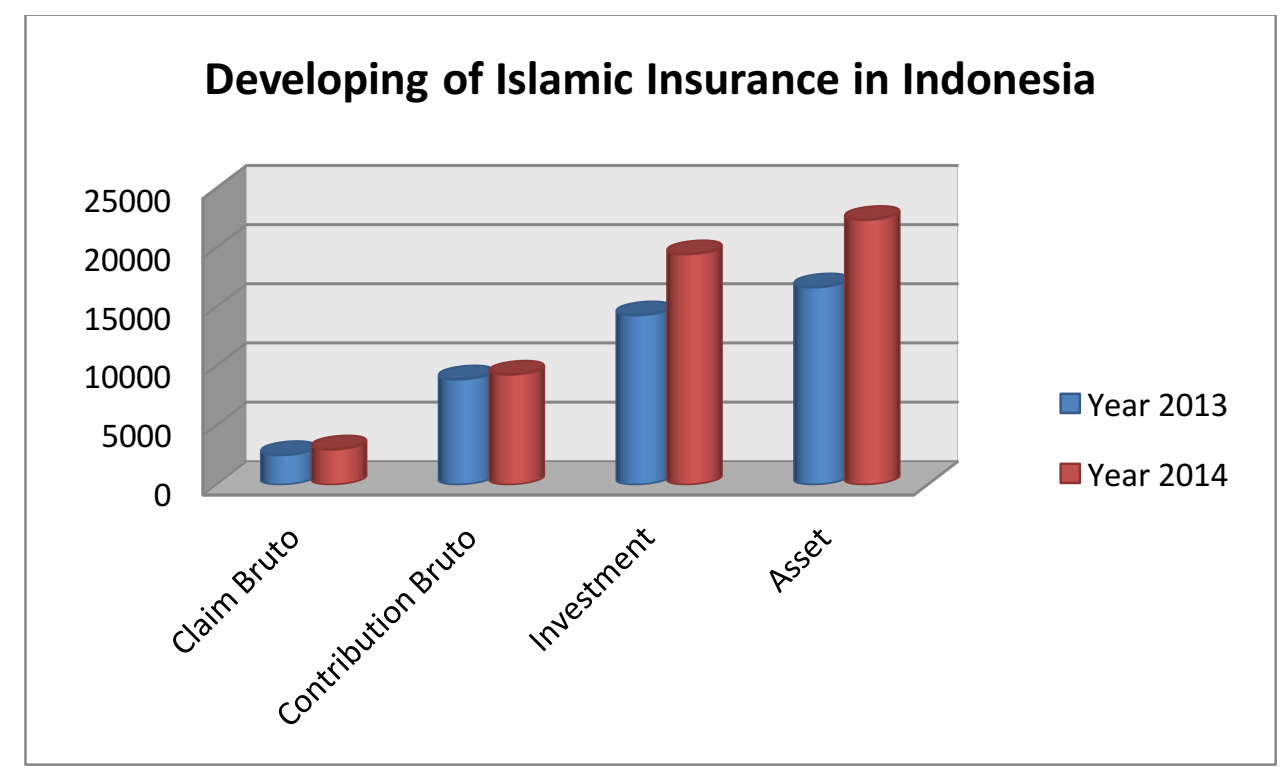

International Journal of Nusantara Islam, Vol.06 No.01 - 2018; (23-144) DOI: https://dx.doi.org/10.15575/ijni.v6i1.3004 


\title{
Figure 2: Developing of Islamic Insurance in Indonesia
}

\author{
Source: Financial Service Authority, Indonesia
}

From the chart above it can be seen that the development of Takaful from 2013 to 2014 based on the chart above generally show a positive trend, in terms of the amount of gross claims, gross contributions, investments and assets. Nevertheless, research conducted by Rusydiana and Nugroho (2017) mentions that in general, conventional insurance instution is relatively more efficient than sharia insurance. This is understandable, because the market share of Takaful is relatively small. The market share of sharia life insurance compared to total national insurance assets is about 6.5\% in February 2017.

Given the very large role of Islamic Financial Institutions especially Takaful in supporting the Indonesia economy, it is necessary to review the public response to the Sharia Insurance in Indonesia over the years. Islamic insurance institutions that are necessary for microtakaful studied is because these institutions are able to reach people in Indonesia below and not much present. Therefore, as a material assessment of the importance of microtakaful, it would require an assessment of public sentiment against microtakaful sentiment and sentiment analysis can be used which is an integral part of the analysis of text mining.

Sentiment analysis or opinion mining is the process of understanding, extract and process the textual data automatically to get the sentiment of information contained in an opinion sentence. Sentiment analysis is done to see opinions or opinions tendency towards a problem or an object by a person, whether or opine tend to view negative or positive. One example of the use of sentiment analysis in the real world is the identification of market trends and market opinion to an object goods. The magnitude of the effect and benefits of sentiment analysis led to research and sentiment analysis based applications is growing rapidly. Even in America, there are about 20-30 companies that focus on sentiment analysis service.

Sentiment analysis or opinion mining is the computational study of the opinions of people, appraisal and emotions through entities, events and attributes of (Biu, L. 2010). The basic task in sentiment analysis is classifying the polarity of the text in the document, sentence, or features/aspects level whether the opinions expressed in the document, a sentence or entity features/aspects are positive, negative or neutral (Dehaff, M., 2010)

In wikipedia, text mining, refers to the process of taking high-quality information from text. High quality information is usually obtained through forecasting patterns and trends through means such as learning statistical patterns. Text mining typically involves structuring processes text input (usually a parsing, along with the addition of some linguistic features derivative and removal of some of them, and subsequent insertion into the database), determine patterns in structured data, and finally evaluate and interpret the output. 'High quality' in the field of text mining usually refers to some combination of relevance, novelty, and interestingness. Typical text mining process include text categorization, text clustering, extraction concept/entity, the production of granular taxonomies, sentiment analysis, inference documents, and entity relationship modeling (ie, learning the relationship between the entities named).

From this background, the authors try to see how the public response or sentiment against the presence or existence microtakaful in Indonesia by using sentiment analysis. This research is expected to provide an overview of related public opinion against microtakaful in Indonesia. So this 
research is expected to contribute to the development of microtakaful in Indonesia. As a comparation so conduct the research in Malaysia.

\section{B. METHOD}

\section{The Types and Source of Data}

In this study used secondary data, ie data derived from the reference or previous research. Secondary data used in this study consisted of 40 specific documents, either in the form of articles and journals related microtakaful in Indonesia. To support the strengthening of the analysis, then added the opinion of an expert mikrotakaful in Indonesia, namely Mister xxx. It is intended to determine expert opinion on the results of the analysis in this study.

\section{Sentiment Analysis Method}

The methodology used in this study is a sentiment analysis or opinion mining. Sentiment Analysis is a commonly used research to gauge public sentiment on a theme issue. Sentiment Analysis is a research branch in the domain Text Mining boom that began in the early 2002's. His research began to flourish since the paper of B. Pang and L. Lee appear. Put simply, text mining to be intended for word processing and not process the numbers.

Sentiment analysis is composed of three major sub processes namely: Subjectivity Classification, Orientation Detection and Opinion Holder \& Target Detection. Until now, most of the research in the field of sentiment analysis is aimed at English because it Tools/Resources for the English very much. Some resources are often used for sentiment analysis is SentiWordNet and WordNet.

The basic task in sentiment analysis is classifying the polarity of the text in the document, sentence, or features/aspects level - whether the opinions expressed in the document, a sentence or entity features/aspects are positive, negative or neutral (Dehaff, M., 2010), Further sentiment analysis can be expressed emotionally sad, happy, or angry.

\section{RESULT AND DISCUSSION}

\section{Economics and Islamic Financial Institutions}

According to Ascarya (2007), contemporary economic and Islamic financial system developed in complete domination of economic and financial system conventional capitalistic. The domination of capitalism inevitably has a big hand in influencing the development of the Islamic financial system and the economy are not always able to directly operate purely in accordance with the Sharia. Moreover, economists are still many Muslims themselves are seized with an inferiority complex who think that the capitalist system is better than the Islamic system, because the evidence is so prosperous developed countries. Furthermore, the implementation of the Islamic system in the capitalist world faced many operational problems that caused it difficult to apply in a pure and devout.

From that description, with a variety of environmental conditions and constraints that exist, it is undeniable that the Islamic financial system and the economy tends to grow more pragmatic, 
permissive, and more follow to what is in the conventional system. As for the contemporary Islamic finance infrastructure developed following the conventional financial infrastructure that is primarily (Ascarya: 2007):

a) Islamic Bank; is a bank conducting business based on Sharia principles, the rule of Islamic law based on the agreement between the bank and other parties to deposit funds and or financing of business activities, or other activities stated in accordance with Shariah (the values of the macro and micro). Islamic banks can take the form of commercial banks (full-fledged), Islamic unit (full branch), rural banks (rural banks), and Islamic products in conventional banks (wi

b) Takaful; is insurance that relies on the concept of mutual help in goodness and piety (wa ta'awanu alal Birri wat taqwa) and protection (at-ta'min), making all participants as a large family to bear one another. The system is governed by eliminating the three elements that are still questionable, namely uncertainty (gharar), gambling (maysir) and usury.

c) Islamic pawnshop; an activity that is free of liens interest by replacing it with the imposition of fees which are fixed to the administration and storage of goods pawn. The cornerstone of this activity is the act Rasululah pawned his armor to a Jew.

d) Islamic Financing Institutions; are financial institutions (finance company), which is managed by the Sharia. These institutions can be shaped leasing company, finance house, and so on.

e) Non Bank Financial Institutions; is a Sharia-based investment management institutions that mobilize funds through equity investments, deposits mudaraba, and make them available to investors who have prospects. Thus, these institutions perform an intermediary role in helping employers find the funds to run or expand its business. LKSBB can take the form of mutual funds, unit of credit (credit unions), community cooperatives, venture capital, and others.

f) Islamic Micro Finance Institutions; is a financial services provider agency micro managed Sharia. These institutions can take the form of sharia cooperatives, Baitul Mal wa tamwil (BMT), and so forth.

g) Mutual funds Sharia (Islamic Investment Fund); is a non-bank financial institutions in the Shariabased activities oriented investment portfolio. Mutual funds Sharia, which is basically the same as the mutual conventional, aims to raise investment funds from the public as the owner of the funds (shahibul mal), managed by investment managers as a manager (mudharib), then invested in financial instruments of sharia that are traded in the capital market and the market sharia money. The fund management must not conflict with Islamic principles, such as not doing usury and suggestive speculation.

h) Islamic Capital Markets; is a vehicle that brings together those who need the funds and those who want to put money, through activities concerned with the public offering and trading of securities, public companies relating to securities issuance, as well as institutions and professions related to the effect, which is run by the principles Sharia.

i) Islamic Money Market; is a vehicle that bridges the intermediary function of Islamic banks in managing their liquidity. Islamic banks are underfunded to meet with Islamic banks with excess funds by means of sharia money market instruments are short term. more

\section{Text Mining}

Text mining or text analytics is a term that describes a technology that can analyze text data semistructured or unstructured, this is what distinguishes it from data mining where the data mining process data that are structured. Basically, text mining is an interdisciplinary field that refers to the 
acquisition of information (information retrieval), data mining, machine learning (machine learning), statistical, and computational linguistics (Jiawei, et al, 2012). In general, the concept of work is similar to the text mining data mining, the excavation predictive and descriptive excavation. Text mining to extract meaningful numerical index of the text and then the information contained in the text will be accessed using various data mining algorithms (statistical and machine learning) (Miner et al, 2012).

The most common application today does text mining for example filtering spam, sentiment analysis, gauge customer preferences, summarize documents, grouping research topics, and many others. According to Miner et al (2012), text mining jobs are grouped into seven areas of practice:

$>$ The search and acquisition of information (search and information retrieval), the storage and extracting the text document, for example in the search engine (search engine) and search keywords (keywords)

$>$ grouping of the data, the grouping and categorizing words, terms, paragraphs, or document using cluster (clustering) data mining

$>$ Classification of documents, namely grouping and categorizing words, terms, paragraphs, or documents by using the method of classification (classification) data mining based on the trained models that already has a label.

$>$ Web mining, i.e. extracting information from the internet with a specific focus scale.

$>$ Extraction of information (information extraction), which identifies and extracts information from data that is semi-structured or unstructured, and turn it into structured data.

$>$ Natural language processing (NLP), which is making a program that has the ability to understand human language.

$>$ Extraction concept, namely grouping word or phrase into semantically similar groups.

Manual text mining approach extensively in the laboratory first appeared in the mid-1980s, but advances in technology have allowed the sphere to evolve over the past decade. Text mining is an interdisciplinary field that refers to the information retrieval, data mining, machine learning, statistics, and computational linguistics.

Because most of the information (general estimates say more than $80 \%$ ) is currently stored as text, text mining is believed to have high potential commercial value (Bridge, 2011). Currently, text mining has received attention in various fields:

a. Application security.

Lots of text mining software packages marketed to security applications, especially the analysis of plain text such as Internet news. It also includes a study text encryption.

b. Biomedical applications.

Various text mining applications in biomedical literature has been compiled. One example is PubGene that combines text mining of biomedical visualization as a network of Internet services. Another example of text mining is GoPubMed.org. Semantic similarity has also been used by a text mining system, namely, GoAnnotator.

c. Software and Applications

Research and development departments of large companies, including IBM and Microsoft, are researching text mining techniques and develop programs to further automate the process of 
mining and analysis. Text mining software is also being investigated by different companies working in the field of search and indexing in general as a way to improve its performance.

d. Media Applications Online

Text mining is being used by large media companies, such as the Tribune company, to eliminate ambiguous information and to provide the reader with a better search experience, which increases loyalty and revenues at the site. In addition, editors benefited by being able to share, associates and property news package, significantly improving the opportunities to monetize content.

e. Marketing applications

Text mining is also beginning to be used in marketing, more specifically in the analysis of customer relationship management. Coussement and Van den Poel (2008) apply to improve predictive analysis models for customer churn (customer reduction).

\section{f. Sentiment Analysis}

Sentiment Analysis may involve the analysis of movie reviews for estimating how well a review for a movie. This kind of analysis may require data set labeled or label of effectiveness words. A resource for the effectiveness of the words have been made to WordNet

\section{g. Academic applications}

Text mining issue is important for publishers who have a huge database to obtain information that requires indexing to search. This is especially true in science, where often very specific information contained in the written text. Therefore, initiatives have been taken such as Nature's proposal to Open Text Mining Interface (OTMI) and Health's common Journal Publishing for Document Type Definition (DTD), which will provide cues semantics on the machine to answer specific questions contained in the text without losing the barrier publishers public access. Previously, the website most frequently used text-based search, which only find documents that contain the words or phrases specified by the user specific. Now, through the use of semantic web, text mining can find content based on meaning and context (rather than just a particular word). Text mining is also used in some email spam filters as a way to determine the characteristics of messages that may be an ad or other unwanted material.

\section{Sentiment Analysis}

Sentiment analysis or opinion mining refers to a broad field of natural language processing, computational linguistics and text mining. In general, it aims to determine the attitude of the speaker or writer with respect to a particular topic. Attitude may assessment or evaluation of them, a statement of their affective (emotional statement authors when writing) or the intended emotional communication (emotional effect the author wants to readers). The basic task in sentiment analysis is classifying the polarity of the text in the document, sentence, or features / aspects level - whether the opinions expressed in the document, a sentence or entity features / aspects are positive, negative or neutral (Dehaff, M., 2010) , Further sentiment analysis can be expressed emotionally sad, happy, or angry

Some studies classify the polarity of the document on a scale of multi-directional, attempted by (Pang, B. \& Lee, L. 2005) and (Snyder B. \& R. Barzilay 2007) include: extending the basic task of classification review of the movie as a positive or negative to predict a good star rating scale 3 or 4, while (Snyder B. \& R. Barzilay 2007) conducted in-depth analysis on a restaurant review, 
predicting the ratings for various aspects of the restaurant are given, such as the food and atmosphere (in a five-star scale)

A different method to determine the sentiment is the use of large-scale systems where the words commonly associated sentiment negative, neutral or positive with those given a number on a scale of -5 to +5 (most negative to the most positive) and when a piece of structured text analyzed natural language processing, concept further analyzed to understand these words and how they relate to the concept. Each concept was then given a score based on how words relate to the concept of sentiment, and the scores were related. This allows the movement to a more sophisticated understanding of sentiment based on a 11-point scale.

Research in a different direction is the identification of subjectivity/objectivity. This task is usually defined as classify a given text (usually a sentence) into one of two classes: objectively or subjectively (Pang, B. \& Lee, L, 2008). This problem can sometimes be more difficult than the classification polarity (Mihalcea, R. et al, 2007) subjectivity words and phrases may depend on the context and objective document may contain subjective words (for example, a news article quoting the opinion of people)

In addition, as mentioned by (Su, F. \& Markert, K. 2008), the results are highly dependent on the definition of subjectivity used when annotate text. However, (Pang, B. \& Lee, L. 2004) shows that removing an objective sentence of a document before classifying polarity help improve performance

We can track their products, brands and people, for example, and determine whether they are positive or negative views on the web. It allows a business to keep track of: Perception of a new product, brand perception, reputation management and other related issues.

Expression or sentiment refers to the focus of specific topics, a statement on the topic may be different meanings to the same statement on different subject. For example, is a good thing to say the flow of the film are not predictable, but it is not a good thing if the 'unpredictable' is stated on the steering wheel of the vehicle. Even on a particular product, the same words can describe the meaning of the opposite, examples are a bad thing for a start-up time on the digital camera if it is declared "old", but if the "old" age stated on the battery it will be a positive thing. Therefore, in some studies, especially on the product review, work was preceded by defining the elements of a product that is being discussed before starting the process of opinion mining (Barber, 2010).

First thing in the processing of documents is to break down a group of characters in the word or token, often referred to as tokenisasi. Tokenisasi is complex for computer programs as some characters can be found as token delimiters. Delimiter is the character of spaces, tabs and new line "newline", while the character () <> !? Sometimes used as a delimiter but sometimes not depends on the environment (Wulandini, F. \& Nugroho, A. N. 2009).

\section{Empirical Study}

Research on text mining or sentiment analysis has been carried out. As for some summaries of previous studies related to the implementation of opinion mining (text mining) as follows:

Research on sentiment analysis performed by Ahmed Abbasi, Hsinchun Chen, \& Saudi Salem titled Sentiment Analysis in Multiple Languages: Feature Selection for Opinion Classification in Web Forums, found that the method of hybridization of genetic algorithm EWGA get a better result than the method of SVM weight for feature selection. As for the classification process, itself is done by 
the SVM method. EWGA method is a combination of heuristic methods Information Gain (IG) with random method of Genetic Algorithm (Saraswati: 2011).

Rozi et al (2012) examined the Public Opinion Data Extraction in Higher Education. In this research, opinion mining system developed to analyse public opinion in college. In the document sub process subjectivity and detection targets used Part-of-Speech (POS) Tagging using Hidden Makov Model (HMM). On the results of the process of POS Tagging then applied the rule to determine whether a document including opinions or not, and to know which part of the sentence which is the object of the target opinion. Documents that are recognized as opinion is further classified into positive and negative opinion (Opinion sub processes orientation) using a Naive Bayes classifier (NBC). From the test values obtained precision and recall for sub processes document subjectivity is 0.99 and 0.88 , for a process are 0.92 and 0.93 , and for the opinion sub processes orientation are 0.95 and 0.94 .

Sunni and Widyantoro (2012) analysis on sentiment and sentiment extraction Topics Determinants of People on Public Opinion. Mentioned that the increasingly widespread use of social networks like Twitter makes social networking such as very large data. This study was to determine the opinion or sentiment of social networking users of a topic. One important topic is a public figure, as a candidate for governor, party chairman. The results of the analysis and testing shows the preprocessing stage does not have a significant effect on the accuracy $(69.4 \%-72.8 \%)$ sentiment classification. As for the extraction topic show that use of Tf-Idf with cumulative discounted able to increase the amount of extracted corresponding topics. However, it has a weakness when facing topics contained in almost the entire interval or a topic that is not sourced from news in the internet media.

Faishol (2011) examined the implementation of Text Mining to Support Search Topics In the elibrary Using Mobile Device. This study uses text mining methods that implement the algorithm cosine similarity to document rank (page rank). This is necessary because of the amount so large collection of documents owned by a library, we need a method to rank of these documents when requested. In text mining, there are several important processes, namely the folding case, tokenizing, filtering, and analysis stemming. Stemming used is Porter's algorithm Indonesianlanguage text and the analysis in the document weighting algorithm, TF / IDF and cosine similarity (Vector Space Model). Test data obtained from the central library of the State Islamic University of Malang in the form of abstraction thesis. From the test results obtained that relevant documents are received by users reaches $100 \%$ and accuracy of data relevant to the received data users reached an average of $78.2 \%$.

Saraswati (2011) examined the Text Mining Methods Naïve Bayes classifier and Support Vector Machines for Sentiment Analysis. Text mining is concluded that, referring to the process of taking high-quality information from text. High quality information is usually obtained through forecasting patterns and trends through means such as learning statistical patterns. Typical text mining process include text categorization, text clustering, extraction concept / entity, the production of granular taxonomies, sentiment analysis, inference documents, and entity relationship modelling. In this study discussed the classification of opinions as a positive opinion and a negative opinion on the data and the data speak English Indonesia using Naïve Bayes classifier (NBC) and Support Vector Machine (SVM). Neither NBC nor the method of SVM method provides good performance in sentiment analysis, opinion classification in English and Indonesian language in this study. The experimental results show that the SVM method provides better performance than either method on NBC for classifying opinion positive opinion in English and Indonesian language. While NBC gives better performance in classifying test data of negative opinion in Indonesian language. 
Megawati (2015) examined the aspirations and Complaints Site Report Using Text Mining. The rapid development of Information and Communication Technology (ICT) has made it an important part of everyday life. The government sector in Indonesia is one of the parties who have tried to use ICTs to create a site for two-way communication with the public (e-Governement) in the form REPORT! (Services and Complaints Online People's Aspiration). Reports received from the public can be an important input for the government to assist the construction and improvement of public services. Therefore, this study using text mining to analyze textual data in the form of opinions or complaints by classifying it into several classes and then the data sets of each class will be divided into several topic-specific (cluster). The results showed that the report related to poverty had the highest number with the majority of the topics covered are about some kind of social assistance such as PPP (Social Security Card) and BLSM (Direct Aid Society meantime) are not well distributed or not on target.

Other research on microtakaful done by Rusydiana and Devi (2017). The research objectives of this study are to identify and analyze the problems faced by TWG in developing of micro-takaful institutions and identify the solutions to solve those kinds of problems, by using Analytic Hierarchy Process (AHP) method.

\section{Explanation}

The author tried to calculate sentiment of Islamic micro insurance in Indonesia. As already known, Sentiment Analysis is a commonly used research to gauge public sentiment on a theme issue. As a source of data, selected 40 specific documents, either in the form of articles and journals related to microinsurance sharia in Indonesia. Tools used in this research is Semantria as processing aids. The results of sentiment analysis of the condition of Islamic micro insurance in Indonesia can be seen in the following figure:

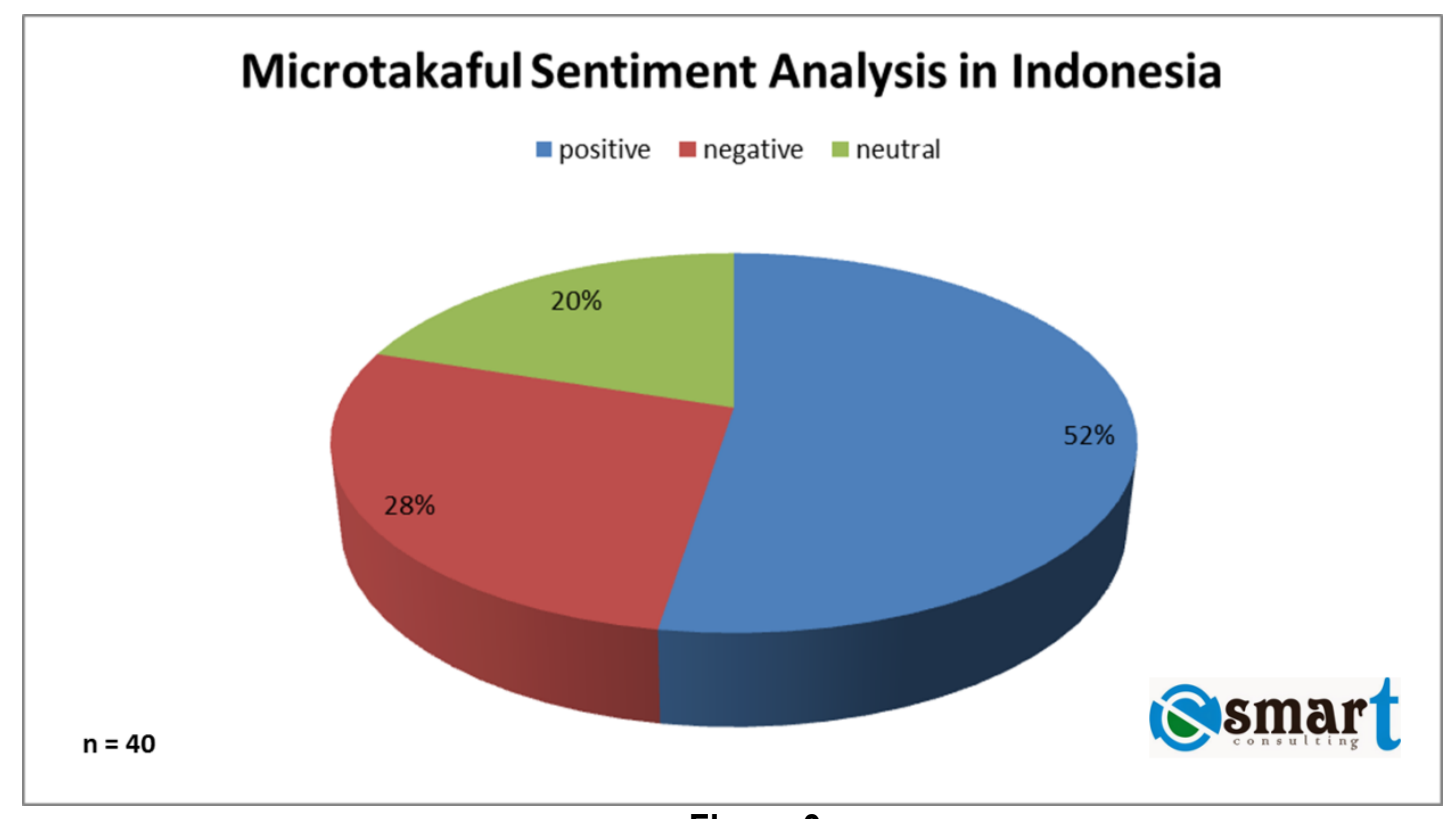

Figure 3:

Microtakaful Sentiment Analysis in Indonesia 
From the picture above we can see that the majority view that the presence microtakaful in Indonesia is very good (positive) precisely as much as $52 \%$. This means that the majority of the literature indicates positive sentiment. Therefore, this situation must be addressed properly by operators including associates. The social demand for Islamic micro insurance should be facilitated with products that suit the needs of society. It required high innovation so that the products made by the insurance company can used by the public. If this is not done, the people will move to another insurer.

In fact, under the public need protection against their assets without having to feel aggrieved because the load is too high. They always take into account the cost and benefit of the products chosen. Companies should be able to pay attention to this condition because a lot of considerations to be made by the public to the products issued by microtakaful. In accordance with the purpose of the presence of microtakaful that the company exists to help lower-income communities to enable them to access financial services on an ongoing basis according to the needs and abilities.

Seeing the excellent public response to the presence of insurance mikrotakaful and when compared with the total population of Indonesia is very much, even half of the population is low income, it shows a very good market share. however, in praktinya still major obstacles in order to develop microtakaful insurance is still low public awareness of insurance as well as the high cost to be incurred by the company. so it must be built the best strategy to penetrate the market share in Indonesia.

While the results showed $28 \%$ negative sentiment and the balance of $20 \%$ indicates a neutral sentiment. This condition must be very reasonable considering the presence of Takaful in particular microtakaful still very new in Indonesia so it will find many challenges including a lack of public confidence in the company. but this should be a race for the company to be able to prove to the public that insurance microtakaful able to help people that by applying the principles of sharia in practice so that products released will be well received and insurance institutions will develop in Indonesia.

This is as it has been presented by Mohammad Obaidullah, IRTI IDB researchers that the potential of microfinance in general are very prospective. Even Obaidullah has repeatedly come to Indonesia to examine the concept of microfinance, including micro-insurance sharia. Indonesian microfinance industry according to become established system even compared to other countries in the world. Therefore, it is possible in the future to build Indonesian microfinance model to be replicated in the international world.

As a comparative assessment of the existence microtakaful community in Indonesia, the research has also been conducted in Malaysia. Results of analysis can be seen in the following figure: 


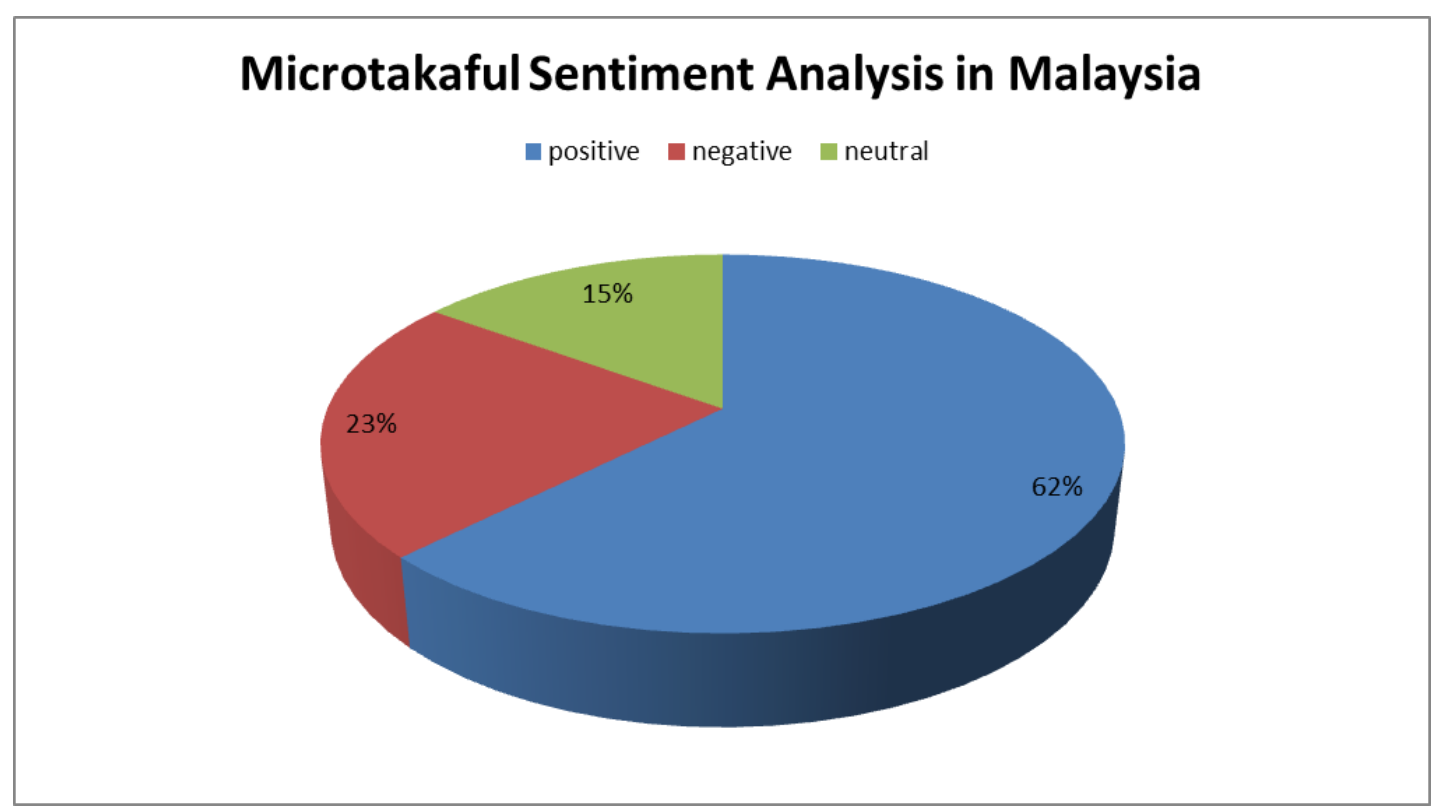

Figure 4:

Microtakaful Sentiment Analysis in Malaysia

Based on the analysis above, we can see that as much as $62 \%$ of Malaysian society a positive view on the existence of microtakaful. This sentiment is certainly greater than the sentiment in Indonesia is only $52 \%$. This reinforces the evidence that aspects of Islamic finance in Malaysia superior Indonesia. Other research results regarding the negative sentiment that only $23 \%$ were neutral and only $15 \%$.

In Indonesia, microtakaful development is part of financial inclusion programs. Currently, there are 65 companies out of 140 that sell microinsurance products (OJK, 2016). It should be linked and interconnected with other initiatives on financial inclusions such as digital payment, branchless banking, microfinance etc. Today, microtakaful development need for coordinating forum between OJK, associations, insurance/takaful companies and distribution channels as well as communities is a key for product designing, knowledge sharing, and joint public awareness campaign. It is also need for coordination among various government agencies to strengthen financial inclusion initiatives

\section{CONCLUSIONS}

Based on the results of text mining analysis of writings, articles and journals about microtakaful in Indonesia and in Malaysia it can be concluded that: The majority of the positive sentiment in Indonesia against microtakaful attendance was $52 \%$ while in Malaysia as much as $62 \%$. So that the positive sentiment in Malaysia is greater than in Indonesia. The negative sentiment on microtakaful presence in Indonesia as much as $28 \%$, while in Malaysia as much as $23 \%$. So that the negative sentiment in Malaysia less than in Indonesia. Sentiment Neutral on microtakaful presence in Malaysia as much as 15\%, while in Indonesia by $20 \%$.

Suggestions presented in this paper are: It takes a number of articles to find out more on the existence microtakaful public sentiment in Indonesia and Malaysia in order to become better analytical results. Research can be done also in other countries such as ASEAN, ASIA that in the World. For policy output, microtakaful development need for coordinating forum between OJK, 
associations, insurance/takaful companies and distribution channels as well as communities is a key for product designing, knowledge sharing, and joint public awareness campaign.

\section{REFERENCES}

Abidin, Z. 2007. "Kinerja Efisiensi Pada Bank Umum." Proceeding PESAT (Psikologi, Ekonomi, Sastra, Arsitek \& Sipil), 2(8): 113-119.

Ascarya, Yumanita, Diana, and Anwar Enny. 2006. Sinergi Sistem Keuangan Konvensional dan Sistem Keuangan Islam. Occasional Paper, Central Education and Banking Study- Bank Indonesia.

Ascarya. 2007. Sistem Keuangan dan Moneter Islam. Central Education and Banking Study - Bank Indonesia. Bank Indonesia.

Barber, I. 2010. Bayesian Opinion Mining.

Biu, L. 2010. Sentiment Analysis: A Multi-Faceted Problem.

Bridge, C. 2011. Unstructured Data and the 80 Percent Rule.

Coussement, K. \& Poel, V. D. 2008. Integrating the Voice of Customers through Call Center Emails into a Decision Support System for Churn Prediction.

Dehaff, M. 2010. Sentiment Analysis, Hard But Worth It!.

Faishol, Muh Anas. 2011. "Implementasi Text Mining Untuk Mendukung Pencarian Topik Pada elibrary Menggunakan Mobile Device". Technique Informatika Department. University of Islam Negeri Maulana Malik Ibrahim: Malang.

FSA. 2013. Financial Service Act. Bank Negara Malaysia.

Hussein, Mumtaz, Asghar Shahmoradi, dan Rima Turk. 2015. An Overview of Islamic Finance. International Monetery Fund Working Paper June, 15/120.

Islamic Financial Services Board. 2014. Strenghtening the Financial Safety Net: The Role of Shariah-Compliant Lender-of Last-Resort Facilities as an Emergency Financing Facility. IFSB Working Paper. Kuala Lumpur, Malaysia: IFSB.

Jiawei, H., Kamber, M., \& Pei, J. 2012. Data Mining: Concepts and Techniques Third Edition. Waltham, MA: Morgan Kaufmann.

Megawati, Chyntia. 2015. "Analisis Aspirasi dan Pengaduan di Situs LAPOR! Dengan Menggunakan Text Mining". Faculty of Technique : Universitas Indonesia.

Mihalcea, R. Banea, C. \& Wiebe, J. 2007. Learning Multilingual Subjective Language via CrossLingual Projections. Proceedings of the Association for Computational Linguistics (ACL). pp. 976-983.

Miner, G., Delen, D., Elder, J., Fast, A., Hill, T., \& Nisbet, R. (2012). Practical Text Mining and Statistical Analysis for Non-Structured Text Data Applications. Oxford: Elsevier. 
Nurfalah, I., Rusydiana, A.S., Laila, N., and Cahyono, E.F. (2018), "Early warning to banking crises in the dual financial system in Indonesia: The markov switching approach", JKAU: Islamic Economics, Vol.31, No.2, pp.133-156.

Otoritas Jasa Keuangan. 2013. Laporan Perkembangan Keuangan Syariah 2013.

Pang, B. \& Lee, L. 2008. Subjectivity Detection and Opinion Identification. Opinion Mining and Sentiment Analysis. Now Publishers Inc.

Pang, B. \& Lee, L. 2004. A Sentimental Education: Sentiment Analysis Using Subjectivity Summarization Based on Minimum Cuts. Proceedings of the Association for Computational Linguistics (ACL). pp. 271-278.

Pang, B. \& Lee, L. 2005. Seeing stars: Exploiting class relationships for sentiment categorization with respect to rating scales. Proceedings of the Association for Computational Linguistics (ACL). pp. 115-124.

Rozi, Imam Fahrur, Sholeh Hadi Pramono dan Erfan Achmad Dahlan. 2012. "Implementasi Opinion Mining (Analisis Sentimen) untuk Ekstraksi Data Opini Publik Pada Perguruan Tinggi" Jurnal EECCIS 6(1).

Rusydiana, A.S., and Devi, A. 2017. "Development strategy of micro-takaful institutions: Case study working group Indonesia", Etikonomi, Vol.16(2), pp.265-278.

Rusydiana, A.S., and Nugroho, T. 2017. "Measuring efficiency of life insurance institution in Indonesia: Data envelopment analysis approach", Global Review of Islamic Economics and Business, Vol.5, No.1, pp.12-24.

Saraswati, Ni Wayan Sumartini. 2011. "Text Mining Dengan Metode Naïve Bayes Classifier dan Support Vector Machines Untuk Sentiment Analysis". Program Pasca Sarjana Universitas Udayana: Denpasar.

Snyder B. \& Barzilay R. 2007. Multiple Aspect Ranking using the Good Grief Algorithm. Proceedings of the Joint Human Language Technology/North American Chapter of the ACL Conference (HLT-NAACL). pp. 300-307.

Statsoft. (2015). Text Mining Introductory Overview.

Su, F. \& Markert, K. 2008. From Words to Senses: a Case Study in Subjectivity Recognition. Proceedings of Coling 2008, Manchester, UK.

Sunni, Ismail dan Widyantoro, Dwi H. 2012. "Analisis Sentimen dan Ekstraksi Topik Penentu Sentimen Pada Opini Terhadap Tokoh Publik". Jurnal Sarjana Institut Teknologi Bandung Bidang Teknik Elektro dan Informatika 1(2).

Wulandini, F. \& Nugroho, A. N. 2009. Text Classification Using Support Vector Machine for Webmining Based Spation Temporal Analysis of the Spread of Tropical Diseases. International Conference on Rural Information and Communication Technology 2009. 